\title{
Wnt Signaling Promotes Regeneration in the Retina of Adult Mammals
}

\author{
Fumitaka Osakada, ${ }^{1,2,3 *}$ Sotaro Ooto ${ }^{4 *}$ Tadamichi Akagi, ${ }^{4}$ Michiko Mandai, ${ }^{1}$ Akinori Akaike, ${ }^{3}$ and Masayo Takahashi ${ }^{1,2}$ \\ ${ }^{1}$ Laboratory for Retinal Regeneration, Center for Developmental Biology, RIKEN, Kobe 650-0047, Japan, ${ }^{2}$ Department of Experimental Therapeutics, \\ Translational Research Center, Kyoto University Hospital, Kyoto 606-8507, Japan, ${ }^{3}$ Department of Pharmacology, Graduate School of Pharmaceutical \\ Sciences, Kyoto University, Kyoto 606-8501, Japan, and ${ }^{4}$ Department of Ophthalmology and Visual Sciences, Graduate School of Medicine, Kyoto \\ University, Kyoto 606-8507, Japan
}

Regeneration in the mammalian CNS is severely limited. Unlike in the chick, current models hold that retinal neurons are never regenerated. Previously we demonstrated that, in the adult mammalian retina, Müller glia dedifferentiate and produce retinal cells, including photoreceptors, after acute neurotoxic injury in vivo. However, the number of newly generated retinal neurons is very limited. Here we demonstrate that Wnt (wingless-type MMTV integration site family)/ $\beta$-catenin signaling promotes proliferation of Müller glia-derived retinal progenitors and neural regeneration after damage or during degeneration. Wnt3a treatment increases proliferation of dedifferentiated Müller glia $>20$-fold in the photoreceptor-damaged retina. Supplementation with retinoic acid or valproic acid induces differentiation of these cells primarily into $\mathrm{Crx}$ (cone rod homeobox)-positive and rhodopsin-positive photoreceptors. Notably, injury induces nuclear accumulation of $\beta$-catenin, cyclin D1 upregulation, and Wnt/ $\beta$-catenin reporter activity. Activation of Wnt signaling by glycogen synthase kinase- $3 \beta$ inhibitors promotes retinal regeneration, and, conversely, inhibition of the signaling attenuates regeneration. This Wnt3a-mediated regeneration of retinal cells also occurs in $r d$ mice, a model of retinal degeneration. These results provide evidence that Wnt/ $\beta$-catenin signaling contributes to CNS regeneration in the adult mammal.

Key words: eye; glia; neural stem cell; regenerative medicine; repair; drug

\section{Introduction}

Since the discovery of neurogenesis in the adult mammalian brain, much progress has been made in stem cell biology. New neurons are continuously generated in the subventricular zone of the lateral ventricle and the subgranular zone of the hippocampal dentate gyrus (Gage, 2000; Alvarez-Buylla and Garcia-Verdugo, 2002) and are functionally integrated into neural circuits (van Praag et al., 2002; Jessberger and Kempermann, 2003; SchmidtHieber et al., 2004). Except for these two regions, neurogenesis appears to be extremely limited in the intact adult mammalian CNS. However, after pathological stimulation, such as brain insults, endogenous progenitors do proliferate in regions otherwise considered to be non-neurogenic (Magavi et al., 2000; Arvidsson et al., 2002; Nakatomi et al., 2002). Thus, stimulating these inac-

\footnotetext{
Received Sept. 25, 2006; revised Feb. 20, 2007; accepted March 1, 2007.

This work was supported by Grants-in-Aid from Ministry of Education, Culture, Sports, Science, and Technology and the Leading Project (M.T.). This study was also supported in part by a Grant-in-Aid for Scientific Research from the Japan Society for the Promotion of Science (F.O.). We thank Dr. S. Nakagawa (RIKEN Brain Science Institute, Saitama, Japan) for valuable comments on this manuscript, Drs. T. Kume and H. Katsuki (Kyoto University, Kyoto, Japan) for valuable comments on this work, Dr. Y. Sasai (RIKEN Center of Developmental Biology, Kobe, Japan) for the anti-Crx antibody, Dr. H. Sasaki (RIKEN Center of Developmental Biology) for the TOPGAL transgenic mice, members of the Laboratory for Animal Resources and Genetic Engineering (RIKEN Center of Developmental Biology) for the housing of animals, A. Nomori, K. Iseki, and S. Yokota for excellent technical assistance, and members of the Takahashi laboratory and the Akaike laboratory for stimulating discussions and helpful suggestions.

*F.0. and S.O. contributed equally to this work.

Correspondence should be addressed to Dr. Masayo Takahashi, Laboratory for Retinal Regeneration, Center for Developmental Biology, RIKEN, 2-2-3 Minatojima-minamimachi, Chuo-ku, Kobe, 650-0047, Japan. E-mail: mretina@cdb.riken.jp.

DOI:10.1523/JNEUROSCI.4193-06.2007

Copyright $\odot 2007$ Society for Neuroscience $\quad 0270-6474 / 07 / 274210-10 \$ 15.00 / 0$
}

tive progenitors could produce new neurons to both replace and repair damaged compartments of the CNS.

The retina is a part of the CNS, and the damage to the retina causes irreversible visual impairment. Unlike fish and amphibians, the adult mammalian retina is generally considered to lack the regenerative potential (Raymond and Hitchcock, 2000). Although retinal stem cells exist at the ciliary margin in the adult mammal (Ahmad et al., 2000; Tropepe et al., 2000), whether these mammalian progenitors can promote regeneration in vivo is unknown (Fischer and Reh, 2003). Previously, we demonstrated that Müller glia in the adult mammalian retina are a potential source of stem cells to support retinal regeneration in vivo and that Müller glia-derived progenitors have the potential to differentiate into multiple lineages of retinal cells under the control of intrinsic or extrinsic factors (Ooto et al., 2004). However, few cells are generated from Müller glia, and the photoreceptor cells derived from these cells are too few to compensate for retinal damage. Therefore, efficient strategies to expand intrinsic progenitors, if successful, may greatly contribute to neural regeneration therapy.

Wnt (wingless-type MMTV integration site family) proteins play important roles in multiple developmental events during embryogenesis, such as body axis formation and development of the limbs (Wodarz and Nusse, 1998). In the CNS, the family of Wnt proteins is crucial for axis patterning, cell fate specification, cell proliferation, axon guidance, as well as dendrite and synapse development (Hall et al., 2000; Domingos et al., 2001; Kiecker and Niehrs, 2001; Lyuksyutova et al., 2003). Despite their impor- 
tance in cancer (Polakis, 2000; Reya and Clevers, 2005), little was known about the roles of Wnt signaling in the adult CNS because genetic manipulation of the Wnt pathway often resulted in embryonic lethality. However, alternative methods have revealed that Wnt signaling regulates various stem cell populations, even in adult mammals. For example, Wnt3a controls the self-renewal of hematopoietic stem cells (Reya et al., 2003). In addition, Wnt3 participates in adult neurogenesis in the hippocampus (Lie et al., 2005). Within the retina, Wnt2b maintains the proliferative and undifferentiated state of retinal stem cells in the ciliary marginal zone during development in chicks (Kubo et al., 2003). Wnt3a also promotes proliferation of isolated retinal stem cells in vitro (Inoue et al., 2006). Despite these lines of evidence, roles for Wnt signaling in the regeneration process after adult CNS injury with regard to intrinsic progenitor cells are unresolved.

Here we describe a role for the Wnt/ $\beta$-catenin signaling pathway in adult retinal regeneration and demonstrate that activating this pathway augments neural regeneration in adult mammals. The present findings illustrate the possibilities for manipulating Wnt signaling as a component of regenerative therapies for the adult CNS.

\section{Materials and Methods}

Animals. The use of animals in this study was in accordance with the Guidelines for Animal Experiments of Kyoto University. All animal experiments in this study were conducted with the approval of the Animal Research Committee, Graduate School of Medicine of Kyoto University. Male DA rats (6-7 postnatal weeks) and retinal degeneration $(r d)$ mice (a model of retinal degeneration, postnatal $12 \mathrm{~d}$ ) were purchased from Nihon SLC (Shizuoka, Japan). Ternary complex factor (Tcf) optimal promoter $\beta$-galactosidase ( $\beta$-gal) reporter transgenic mice (TOPGAL transgenic mice) were obtained from The Jackson Laboratory (Bar Harbor, ME) (DasGupta and Fuchs, 1999). These animals are maintained under a $12 \mathrm{~h}$ light/dark cycle with access to food and water ad libitum. Male cynomolgus monkeys (Macaca fascicularis, 4-5 years) were obtained from Keari (Wakayama, Japan) and housed individually under a $12 \mathrm{~h}$ light/dark cycle.

Retinal explant cultures. The retinal explant cultures were prepared as described previously (Hatakeyama and Kageyama, 2002; Ooto et al., 2004). Briefly, eyes were enucleated from rats or mice, and the neural retina was separated from the cornea, the sclera, the lens, the iris, the ciliary body, and the pigmented epithelium. The neural retina was placed onto a microporous membrane (30 $\mathrm{mm}$ in diameter; Millicell-CM; Millipore, Bedford, MA) with the ganglion cell layer (GCL) facing up and placed in a six-well culture plate. Each well contained $1 \mathrm{ml}$ of culture medium consisting of $50 \%$ minimum essential medium/HEPES (Sigma, St. Louis, MO), 25\% HBSS (Invitrogen, Tokyo, Japan), and 25\% heatinactivated horse serum (Invitrogen, Tokyo, Japan) supplemented with $200 \mu \mathrm{M} \mathrm{L}$-glutamine and $5.75 \mathrm{mg} / \mathrm{ml}$ glucose. Explants were maintained

Table 1. List of primers used for PCR

Primer sequence

\begin{tabular}{|c|c|c|}
\hline \multirow[b]{2}{*}{ Gene } & \\
\hline & Forward & Reverse \\
\hline Frizzled-1 & 5'-CTCTTCACGGTGCTCACGTA-3' & $5^{\prime}$-CAGAAAACACACTCCGCTC-3' \\
\hline Frizzled-4 & 5'-AACCTCGGCTACAACGTGAC-3' & 5'-CGATGGGGATGTTGATCTTC-3' \\
\hline Frizzled-9 & 5'-ATGTGATCCAGGAGGGTTTG-3' & 5'-AACTGGTGCCCAGTACCAAG-3' \\
\hline LRP-5 & 5'-AGGGAGCCCTTCTACTCCTG-3' & 5'-CTCGGTGTTCACAAGGGTCT-3' \\
\hline LRP-6 & 5'-GAGTTGGATCAACCCAGAGC-3' & 5'-AAAGGATGTGGAAGGGAACC-3' \\
\hline Dishevelled & 5'-GGTGCACGCCTACAAATTCT-3' & 5'-TCCATTCCATCTCGGCTACT-3' \\
\hline Axin-1 & 5'-GCTCACCCAGAAGCTGCTA-3' & 5'-TCACTGTCATTGGCACTGGT-3' \\
\hline GSK-3 $\beta$ & $5^{\prime}$-CCACAGAACCTCTTGCTGGA-3' & $5^{\prime}$-CCAACTGATCCACACCACTG-3' \\
\hline$\beta$-Catenin & 5'-AGATGTGGACACCTCCCAAG-3' & 5'-GCTGGTGAACCATAACAGCA-3' \\
\hline CyclinD1 & 5'-GCGTACCCTGACACCAATCT-3' & $5^{\prime}$-GGCTCCAGAGACAAGAAACG-3' \\
\hline$\beta$-Actin & 5'-CAACCTTCTTGCAGCTCCTC-3' & 5'-TTCTGACCCATACCCACCAT-3' \\
\hline
\end{tabular}

in a humidified atmosphere of $5 \% \mathrm{CO}_{2}$ and $95 \%$ air at $34^{\circ} \mathrm{C}$. Culture medium was changed every other day. $5^{\prime}$-Bromo-2'-deoxyuridine (BrdU) $(5 \mu \mathrm{g} / \mathrm{ml}$; Sigma) was added to the culture medium for $4 \mathrm{~d}$. Recombinant mouse Wnt3a (10-100 ng/ml; R \& D Systems, Minneapolis, MN), Frizzled-1-cysteine rich domain (Frizzled-1-CRD) (200 ng/ ml; R \& D Systems), dickkopf-1 (Dkk-1) (100 ng/ml; R \& D Systems), SB216763 [3-(2,4-dichlorophenyl)-4-(1-methyl-1H-indol-3-yl)- $1 H$ pyrrole-2,5-dione] (5 $\mu \mathrm{m}$; Sigma), AR-A014418 [N-(4-methoxybenzyl)$N^{\prime}$-(5-nitro-1,3-thiazol-2-yl)urea] (5 $\mu \mathrm{m}$; Calbiochem, San Diego, CA), alltrans retinoic acid (RA) (0.3 $\mu \mathrm{m}$; Sigma), and valproic acid (VPA) (1 mM; Sigma) were applied to the culture medium for the indicated time periods. The control group in all sets of experiments received treatment with the corresponding vehicle $(0.1-0.2 \%$ PBS or $0.05 \%$ DMSO) and BrdU (5 $\mu \mathrm{g} / \mathrm{ml})$.

Fixation, sectioning, and immunohistochemistry. Tissues were fixed, sectioned, and immunolabeled as described previously (Ooto et al., 2004; Ikeda et al., 2005). For preparation of the non-injured retina, animals were perfused transcardially with $4 \%$ paraformaldehyde in $0.1 \mathrm{M}$ phosphate buffer before enucleation of eyes. The primary antibodies and their working dilutions were as follows: mouse anti-BrdU (1:100; Roche, Indianapolis, IN), rat anti-BrdU (1:100; Oxford Biotechnology, Kidlington, UK), mouse anti-Ki-67 (1:200; BD PharMingen, San Diego, CA), mouse anti-glutamine synthetase (GS) (1:1000; Chemicon, Temecula, CA), rabbit anti-GS (1:1000; Sigma), mouse anti-nestin (1:1000; BD PharMingen), rabbit anti-Pax6 (paired box gene 6) (1:600; Covance, Princeton, NJ), sheep anti-Chx10 (ceh-10 homeodomain containing homolog) (1: 1000; Exalpha, Boston, MA), mouse anti-rhodopsin (RET-P1; 1:2000; Sigma), rat anti-Crx (cone rod homeobox) (1:200) (Ikeda et al., 2005), rabbit anti-protein kinase C (PKC) (1:1000; Sigma), mouse anti-PKC (1:500; Sigma), rabbit anti-calbindin (1:200; Chemicon), mouse anti-calbindin (1:200; Sigma), mouse anti-syntaxin (HPC-1; 1:2000; Sigma), rabbit anti-Thy1.2 (1:100; BD PharMingen), mouse anti- $\beta$-catenin (1:300; BD PharMingen), and rabbit $\beta$-gal (1:1000; Cappel,West Chester, PA). The secondary antibodies used were as follows: anti-mouse IgG, anti-rabbit IgG, anti-rat IgG, and anti-sheep IgG antibodies conjugated with cyanine 3, FITC (1:300; Jackson ImmunoResearch, West Grove, PA), or Alexa Fluor 488 or Alexa Fluor 546 (1:1000; Invitrogen, Carlsbad, CA). Apoptotic DNA fragmentation was visualized by terminal deoxynucleotidyl transferase-mediated biotinylated UTP nick end labeling (TUNEL) with the In Situ Cell Death Detection kit (Roche). Cell nuclei were counterstained with 4',6-diamidino-2phenylindole ( $1 \mu \mathrm{g} / \mathrm{ml}$; Invitrogen, Carlsbad, CA). The specimens were imaged with a laser-scanning confocal microscope (Leica, Wetzlar, Germany). The number of immunoreactive cells within an area $(375 \times$ $375 \mu \mathrm{m}$ ) of the central retina (1-2 mm from the optic disc) was counted in individual sections. A total of six sections from every five serial sections were examined for each retina.

Dissociated cultures of retinal cells and immunocytochemistry. After $11 \mathrm{~d}$ of culture, retinal explants were dissociated with $0.25 \%$ trypsin in HBSS without $\mathrm{Ca}^{2+} / \mathrm{Mg}^{2+}$. The cells were pelleted, resuspended in HBSS containing $20 \mu \mathrm{g} / \mathrm{ml}$ DNase I, triturated, and plated onto collagen-coated four-well culture slides at a density of $2.0-4.0 \times 10^{5} \mathrm{cells} / \mathrm{cm}^{2}$. After incubation for $3 \mathrm{~h}$ at $37^{\circ} \mathrm{C}$ in $5 \% \mathrm{CO}_{2}$, the cells were fixed with $4 \%$ paraformaldehyde for $10 \mathrm{~min}$ on ice and subjected to immunocytochemistry.

Reverse transcriptase-PCR and quantitative real-time PCR. Total RNA was extracted with RNeasy (Qiagen, Hilden, Germany), treated with RNase-free DNase I, and reverse transcribed with first-strand cDNA synthesis kit (Amersham Biosciences, Buckinghamshire, UK), according to the instructions of the manufacturer. cDNA was used for a template in each PCR experiment with ExTaq (Takara, Shiga, Japan). PCR amplifications were performed as follows: $5 \mathrm{~min}$ at $94^{\circ} \mathrm{C}$; followed by 30 cycles (26 cycles for $\beta$-actin) consisting of $30 \mathrm{~s}$ at $94^{\circ} \mathrm{C}, 30 \mathrm{~s}$ at $59^{\circ} \mathrm{C}$, and $1 \mathrm{~min}$ at $72^{\circ} \mathrm{C}$; and a final $7 \mathrm{~min}$ extension at $72^{\circ} \mathrm{C}$. The PCR 
products were separated by electrophoresis on a $2.4 \%$ agarose gel and detected under UV illumination. For each set of primers, control amplification was performed without addition of reverse transcriptase (RT) to exclude the possibility of genomic DNA contamination. For quantification of cyclin D1 expression, real-time PCR was performed with ABI PRISM 7700 sequence detection system (Applied Biosystems, Foster City, CA). Reactions were performed in duplicate with SYBR Green PCR Master mix (Applied Biosystems). Thermocycling conditions were as follows: $50^{\circ} \mathrm{C}$ for 2 min, $95^{\circ} \mathrm{C}$ for $10 \mathrm{~min} ; 40$ cycles of $95^{\circ} \mathrm{C}, 15 \mathrm{~s}, 60^{\circ} \mathrm{C}, 30 \mathrm{~s}$, and $68^{\circ} \mathrm{C}, 30 \mathrm{~s}$; and $50^{\circ} \mathrm{C}$ for $2 \mathrm{~min}$. Amplification plots and cycle threshold values from the exponential phase of the PCR were analyzed with ABI Prism SDS 1.7 software (Applied Biosystems). Primers used for PCR were listed in Table 1.

Intravitreal injection of drugs. Experiments were performed on male TOPGAL mice (6 week old) with some modifications (Li et al., 2002; Ooto et al., 2004). Mice were anesthetized with an intraperitoneal injection of sodium pentobarbital $(40-50 \mathrm{mg} / \mathrm{kg})$. Two microliters of $20 \mathrm{~mm}$ NMDA (total $40 \mathrm{nmol}$; Sigma) or $200 \mu \mathrm{g} / \mathrm{ml} \mathrm{Wnt3a} \mathrm{(total} 400 \mathrm{ng}$ ) was intravitreally injected with a 33 gauge needle connected a microsyringe after dilation of the mouse pupil with tropicamide and phenylephrine hydrochloride. The tip of the needle was inserted through the dorsal limbus of the eye. For histological analyses, animals were perfused transcardially with $4 \%$ paraformaldehyde in $0.1 \mathrm{~m}$ phosphate buffer, and the eyes were enucleated. The eyes were postfixed with $4 \%$ paraformaldehyde for $5 \mathrm{~min}$ on ice, dehydrated thorough a graded series of sucrose, and embedded in OCT compound (Tissue-Tek; Miles, Elkhart, IN). Consecutive frozen sections were generated on a cryostat at $14 \mu \mathrm{m}$.

Statistical analysis. Data were pooled from at least three independent sets of experiments and are expressed as means \pm SEM. All statistical analyses were performed with GraphPad InStat version 3.0 (GraphPad Software, San Diego, CA). The statistical significance of difference was determined by one-way ANOVA, followed by Tukey's test and Dunnett's test for experiments in Figure $1 B$, and Figures $4 E$ and $6 B$, respectively. Data from Figure $7 C$ were evaluated with an unpaired $t$ test. Probability values $<5 \%$ were considered significant.

\section{Results}

\section{Generation of retinal progenitor-like cells from Müller glia}

We have previously observed that Müller glia can generate retinal neurons after acute injury in vivo (Ooto et al., 2004). To establish an in vitro injury model for the adult retina, we used retinal explants isolated from adult rats (6-7 postnatal weeks). The explants retained retinal architecture for 2 weeks in vitro. However, the outer nuclear layer (ONL) of the explanted retina became gradually thinner. We detected apoptotic cells with a TUNEL assay. After $7 \mathrm{~d}$ in culture, TUNEL-positive $\left(\mathrm{TUNEL}^{+}\right.$) cells were present in the ONL (Fig. $1 \mathrm{~A}$ ), indicating that the outer part of the retina, comprising mostly photoreceptor cells, was damaged in our explant, presumably because of the lack of retinal pigment epithelia. In this injury model, we labeled dividing cells with $\mathrm{BrdU}(5 \mu \mathrm{g} / \mathrm{ml})$ daily. On day 4 in vitro, the explants were examined by immunohistochemistry for BrdU labeling and retinal cell markers. In the explanted damaged retina, some BrdU-positive cells were detected in the inner nuclear layer (INL) and the ONL (Fig. 1C). On average, the central retina (1-2 $\mathrm{mm}$ from the optic disc) contained 3.0 $\pm 1.3 \mathrm{BrdU}$-positive cells per field $(375 \times 375$ $\mu \mathrm{m})$ in the INL and 14.6 $\pm 1.6 \mathrm{BrdU}$-positive cells per field in the ONL (Fig. $1 B, C$ ). To determine what types of retinal cells were labeled with BrdU, we performed double immunostaining with antibodies to BrdU and cell-specific markers. In the retinal explants, BrdU-labeled cells expressed GS (a marker for Müller glial cells) (Fig. 1C, arrowhead). In addition, cells immunoreactive for Ki-67, a nuclear antigen expressed in dividing cells from late $G_{1}$ to $\mathrm{M}$ phase, were observed in the INL of the damaged retina (Fig. $2 A) ; 2.3 \pm 1.4$ cells per field were Ki-67-positive in the INL of the central retina. The Ki-67-positive cells in the INL also expressed
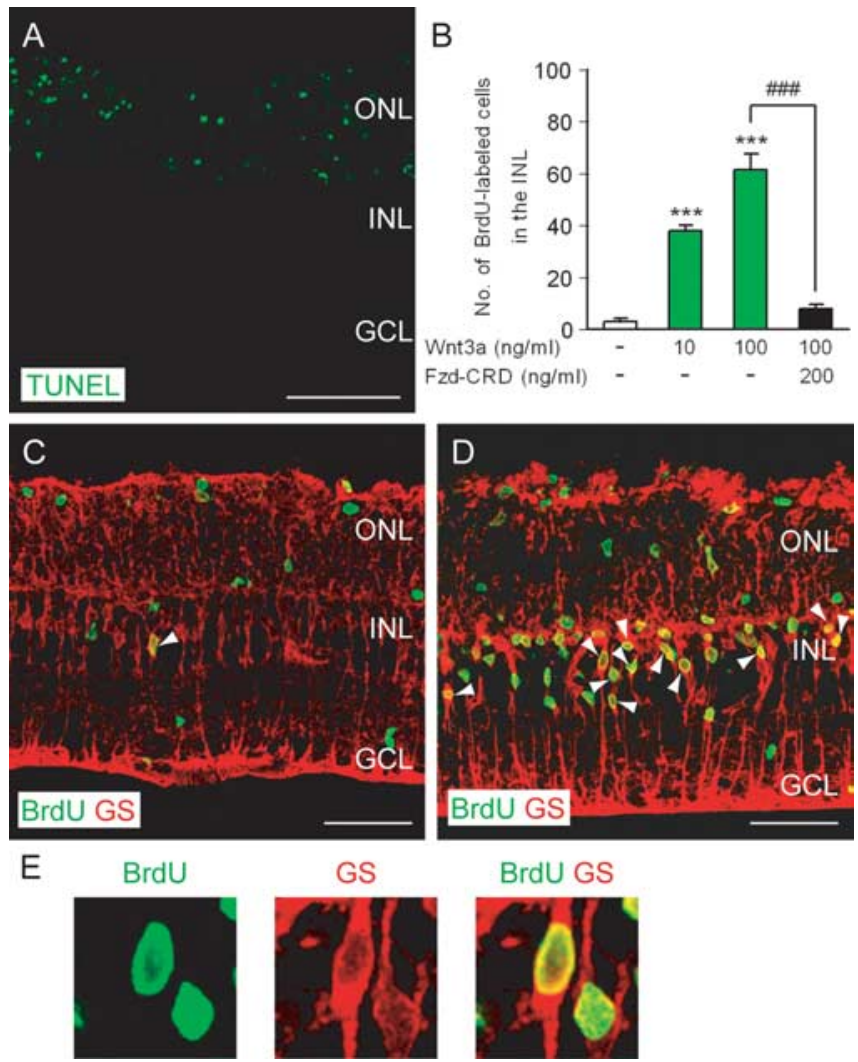

BrdU GS

Figure 1. Mitogenic effect of Wnt3a on Müller glia-derived proliferating cells in adult retinal explants. A, Apoptotic cells were visualized by TUNEL. On day 7, TUNEL-positive cells (green) were detected in the $0 \mathrm{NL}$ of explants from the adult retina, indicating that the retinal explants are an injury model presumably attributable to removal of retinal pigment epithelia. $\boldsymbol{B}$, Concentration dependence of Wnt3a action and its reversal by the Wnt receptor inhibitor. Proliferating cells in retinal explants were labeled with BrdU. The increase of BrdU-positive cells (green) with Wnt3a treatment is blocked by coapplication of Frizzled-1-CRD. ${ }^{* * *} p<0.001$ compared with no treatment; $\# \#>0.001$. Fzd-CRD, Frizzled-1-CRD. C $E$, Confocal photomicrographs of BrdU-labeled proliferating cells. C, BrdU ${ }^{+}$proliferative cells (green) are observed in the damaged retina. A few BrdU-labeled cells (green) in the INL express GS (red) in the retinal explants. $D$, Wnt3a treatment increases the number of BrdU-positive cells (green) positive for GS (red) in the damaged retina. $\boldsymbol{E}$, Magnified view of BrdU (green)/GS (red) double-positive cells in the Wnt3a-treated retina. Retinal explants from adult rats were cultured in the absence $(\boldsymbol{C})$ or presence $(\boldsymbol{D}, \boldsymbol{E})$ of Wnt $3 \mathrm{a}(100 \mathrm{ng} / \mathrm{ml})$ for $4 \mathrm{~d}$ and processed for immunostaining $(n=10)$. Scale bars, $100 \mu \mathrm{m}$.

GS (Fig. 2A). Thus, we conclude that Müller glia reenter the cell cycle in response to injury.

Next, we characterized the regenerative potential of proliferating Müller glia by tracing the cell fates of BrdU-labeled cells. Nestin is a marker for neural progenitors. In the normal retina prepared from perfusion-fixed adult rats, immunoreactivity of nestin was not detected (data not shown). In the retinal explants, a small number of cells expressed nestin (Fig. $2 \mathrm{~A}$ ). Most of the nestin-expressing cells were positive for GS (Fig. $2 A$ ), consistent with Müller glial cells acquiring neural stem cell-like properties. We also examined the expression of Pax6 and Chx10, because only neural retinal progenitors coexpress Pax6 and Chx10 during embryonic retinal development (Belecky-Adams et al., 1997; Marquardt and Gruss, 2002). In the adult rat retina, Pax6 expression is confined to the nuclei of amacrine, ganglion, and horizontal cells; Chx10 expression is restricted to the nuclei of bipolar cells. In the damaged retina, some of GS-positive cells expressed Pax6 (Fig. 2B, arrowhead), and a few BrdU-labeled cells expressed Pax6 (Fig. 2C, arrowhead). In addition, a few cells coex- 

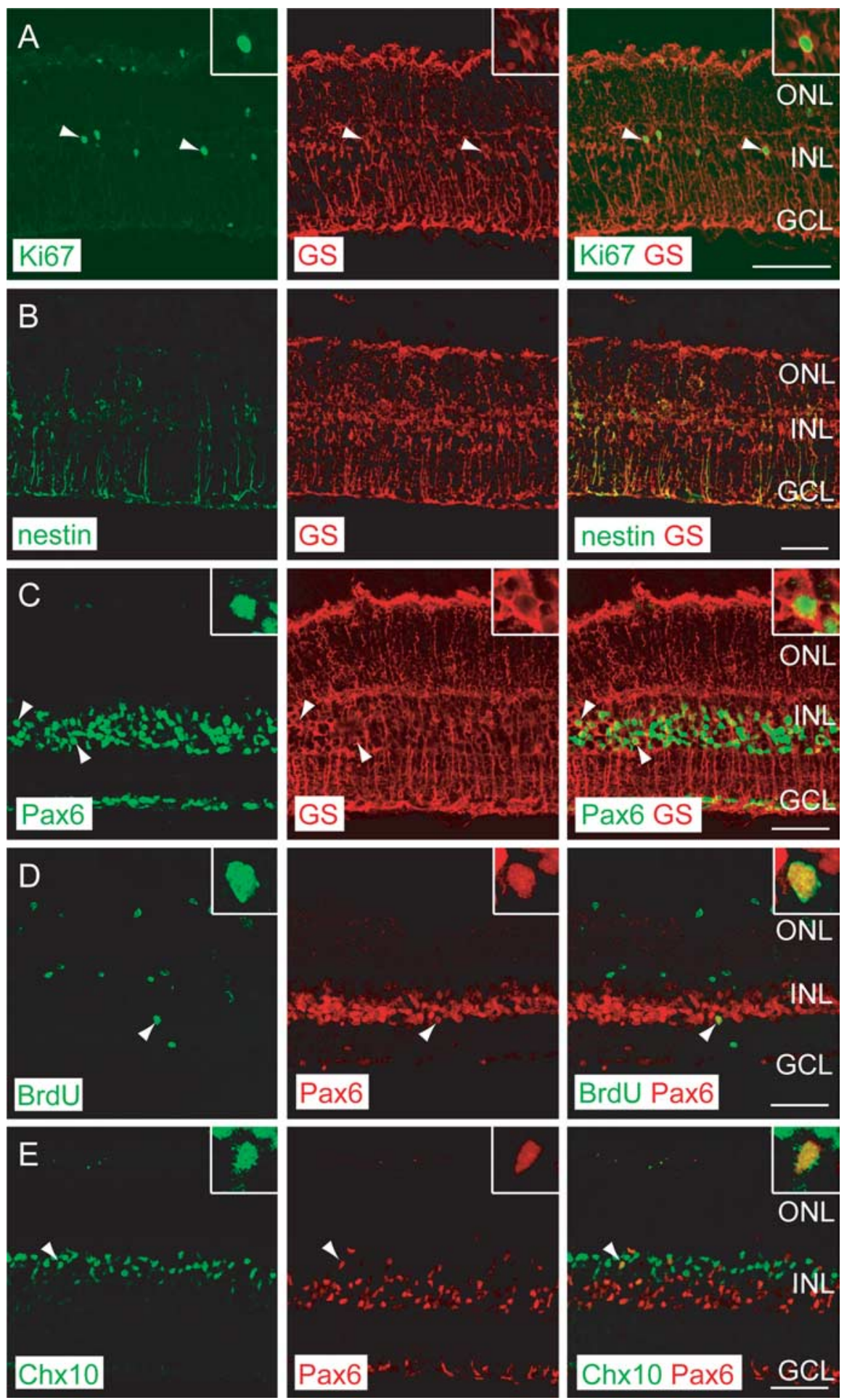

Figure 2. Generation of retinal progenitor-like cells from Müller glia in the retinal explants. $\boldsymbol{A}-\boldsymbol{E}$, Immunohistochemical analyses of the damaged retina. Explants from adult rats were cultured for $4 \mathrm{~d}$ and processed for immunohistochemistry $(n=10)$. Arrowheads, Double-stained cells. Insets, Magnified view of double-labeled cells. A, Ki- $67^{+}$proliferative cells (green) express GS (red) after retinal injury. $\boldsymbol{B}$, After retinal injury, some of GS-positive cells (red) express nestin (green). $\boldsymbol{C}$, In the damage retina, some of GS-positive cells (red) express Pax6 (green). D, A few BrdU-labeled cells (green) express Pax6 (red) in the damage retina. $\boldsymbol{E}$, Retinal progenitor-like cells positive for both Chx10 (green) and Pax6 (red) are present in the INL. Scale bars, $100 \mu \mathrm{m}$.

pressed Pax6 and Chx10 (Fig. 2D, arrowhead): $1.2 \pm 0.5$ cells per field were double positive for Pax6 and Chx10. We conclude that Müller glia proliferate and reenter the cell cycle in response to injury to a limited degree, and that a few of these cells acquire the properties of retinal progenitor-like cells in these retinal explants.
These observations are consistent with our previous study demonstrating the proliferation of Müller glia after acute injury and their subsequent differentiation into new retinal neurons in vivo (Ooto et at., 2004).

\section{Wnt3a promotes proliferation of} dedifferentiated Müller glia

To enhance the regenerative process in the damaged retina, we attempted to identify the growth factors that promote proliferation of dedifferentiated Müller glia. In the present study, we examined the effect of Wnt 3 a on our retinal explants. Treating these explants with Wnt3a $(100 \mathrm{ng} / \mathrm{ml})$ for $4 \mathrm{~d}$ markedly increased the number of BrdU-positive cells in the INL of the central retina as $61.4 \pm 6.3$ cells per field were labeled with BrdU in the INL, and 14.2 \pm 2.5 cells per field were present in the ONL (Fig. 1B,D) (see Fig. 7A). The mitogenic effect of Wnt3a on the adult retina was concentration dependent. A statistically significant effect was observed at concentrations of 10 and $100 \mathrm{ng} / \mathrm{ml}$ (Fig. $1 B$ ). To examine whether Wnt signaling contributed to the increase of BrdU-positive cells, we assessed the effect of Frizzled-1-CRD, a Wnt antagonist, on the number of BrdUpositive cells. After simultaneous application of Frizzled-1-CRD and Wnt3a for $4 \mathrm{~d}$, the number of BrdU-positive cells was reduced to $7.9 \pm 1.7$ cells per field in the INL and $11.9 \pm 1.9$ cells per field in the ONL (Fig. $1 E$ ). The mitogenic effect of Wnt3a is likely mediated by Wnt signaling.

We examined the types of BrdUlabeled cells the in the retinal explants treated with Wnt $3 \mathrm{a}(100 \mathrm{ng} / \mathrm{ml})$. In the INL, $86.4 \pm 3.4 \%$ of the BrdU-labeled cells expressed GS (Fig. 1D,E, arrowheads). Moreover, Wnt3a treatment significantly increased the number of Ki-67-positive proliferating cells $(p<0.001$ compared with the nontreated retina, unpaired $t$ test) because $32.9 \pm 4.5$ cells per field were positive for Ki-67 in the Wnt3a-treated retinal explants (Fig. $3 A$ compared with Fig. $2 A$ ). Most of the Ki-67-positive cells in the INL also expressed GS (Fig. 3A, arrowheads). We conclude that Wnt3a promotes the proliferation of Müller glial cells in the damaged retina.

Next, we determined the effect of Wnt3a on the regenerative potential of proliferating cells. Numerous nestinpositive cells were detected in the sections of retinal explants after Wnt3a treatment $(100 \mathrm{ng} / \mathrm{ml})$ (Fig. 3B). Most of the nestin-expressing cells were GS positive. Although the numbers of $\mathrm{GS}^{+} /$nestin $^{+}$cells, $\mathrm{GS}^{+}$/ $\mathrm{Pax}^{+}$cells, and $\mathrm{BrdU}^{+} / \mathrm{Pax}^{+}{ }^{+}$were small in the explanted retina, these populations increased with application of Wnt3a (100 
ng/ml) (Fig. 3B-D compared with Fig. $2 B-D$, respectively, arrowheads). In the Wnt3a-treated damaged retina, $59.7 \pm$ $3.7 \%$ of BrdU-labeled cells expressed Pax6 (Fig. 3D, arrowheads). Wnt3a treatment also increased the number of retinal progenitors double positive for Pax6/Chx10 (Fig. $3 E$ ). The number of $\mathrm{Pax} 6^{+} / \mathrm{Chx} 10^{+}$ cells increased to $24.9 \pm 2.7$ cells per field, a significant difference compared with the untreated damaged retina $(p<0.001$, an unpaired $t$ test) (Fig. 3E, arrowheads, compared with Fig. 2E). From these results, we conclude that Wnt3a increases the number of retinal progenitors derived from Müller glia.

\section{A role for canonical $\mathrm{Wnt} / \boldsymbol{\beta}$-catenin signaling in neural regeneration}

In the canonical signaling pathway, Wnt proteins bind to Frizzled and low-density lipoprotein receptor-related protein (LRP), thereby activating Dishevelled, destabilizing Axin-1, and inactivating glycogen synthase kinase (GSK)-3 $\beta$, which subsequently targets $\beta$-catenin to the cell nucleus in which it activates the transcription of target genes such as cyclin D1 (Wodarz and Nusse, 1998). To elucidate the involvement of the $\mathrm{Wnt} / \beta$-catenin signaling pathway in retinal regeneration, we first examined the expression of components of the signaling pathway in the retina. Previous reports have shown that the Wnt receptors frizzled-1, frizzled-3, frizzled-4, frizzled-6, frizzled-7, and frizzled-9 and the Wnt coreceptor LRP-6 are expressed in the INL of the mouse retina by in situ hybridization (Liu et al., 2003; Blackshaw et al., 2004; Van Raay and Vetter, 2004). We also found that the adult rat retina expressed frizzled-1, frizzled-4, and frizzled-9 and LRP-5 and LRP-6 by RT-PCR analysis (Fig. 4A). The adult rat retina also expressed Dishevelled, Axin-1, GSK-3 $\beta$, and $\beta$-catenin (Fig. $4 A$ ).

We next investigated whether Wnt3a proteins activate the canonical pathway by examining the subcellular localization of $\beta$-catenin with immunohistochemistry. In non-injured retinas isolated from perfusion-fixed rats, $\beta$-catenin was abundant beneath the plasma membrane, in the cytoplasm of the cell bodies in INL, and in neurites present in the inner plexiform layer (Fig. $4 B$ ). $\beta$-Catenin exhibited a similar distribution in the damaged retina as well. Interestingly, a small number of cells in the INL exhibited nuclear accumulation of $\beta$-catenin (Fig. $4 C$, arrowheads). In Wnt3a-treated damaged retinas, the nuclear accumulation of $\beta$-catenin was evident in the INL (Fig. $4 D$, arrowheads). In addition, quantitative real-time PCR analysis demonstrated that expression levels of
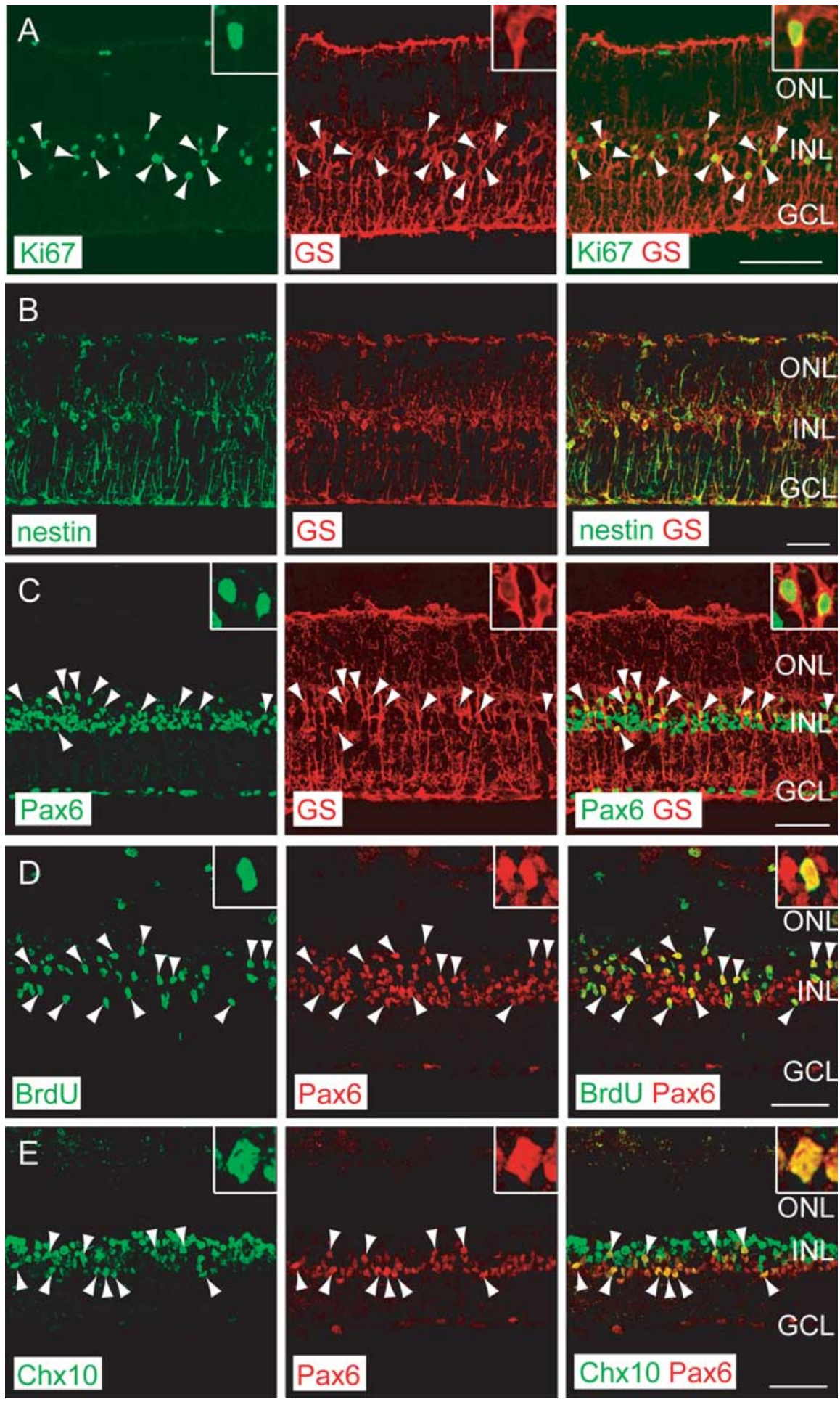

Figure 3. Wnt3a promotes proliferation of Müller glia-derived retinal progenitors. $\boldsymbol{A}-\boldsymbol{E}$, Immunohistochemical analyses of the Wnt3a-treated damaged retina. Retinal explants were treated with Wnt3a $(100 \mathrm{ng} / \mathrm{ml})$ for $4 \mathrm{~d}(n=10)$. Arrowheads, Doublestained cells. Insets, Magnified view of double-labeled cells. $A$, Wnt3a treatment increases Ki-67 (green)/GS (red) double-positive cells in the damaged retina. Arrowheads, Double-stained cells. $\boldsymbol{B}$, Wnt3a treatment increases the number of cells positive for both nestin (green) and GS (red) in the damaged retina. $\boldsymbol{C}-\boldsymbol{E}$, Wnt3a treatment increases the number of retinal progenitor cells positive for Pax6 (green)/GS (red) (C), BrdU (green)/Pax6 (red) (D), and Chx10 (green)/Pax6 (red) (E). Insets, Magnified view of doublelabeled cells in the Wnt3a-treated retina. Scale bars, $100 \mu \mathrm{m}$.

cyclin $D 1$, a known target gene of the Wnt/ $\beta$-catenin signaling pathway (Shtutman et al., 1999; Tetsu and McCormick, 1999) and a key regulator in the progression of $G_{1}$ to $S$ phase in the cell cycling, were upregulated in the damaged retina on day 4 relative 
A

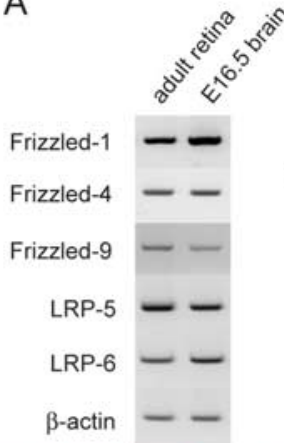

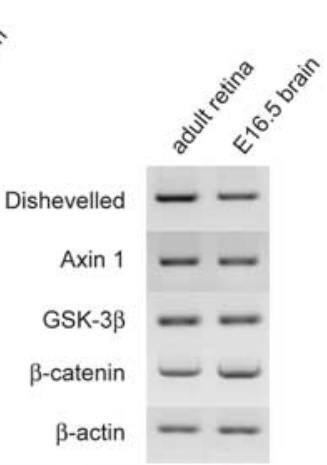

$\mathrm{E}$
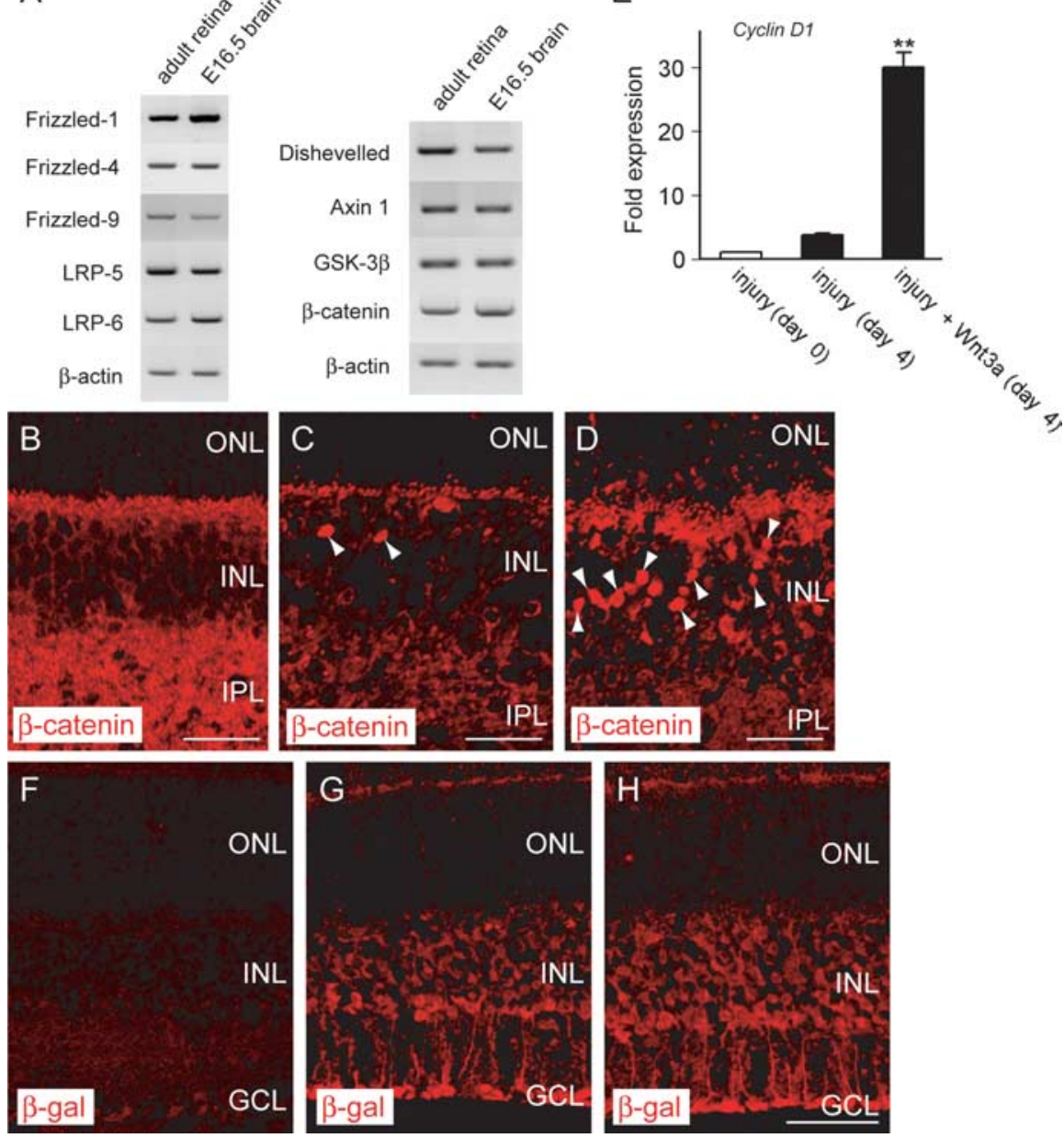

Figure 4. Role for Wnt $/ \beta$-catenin signaling in retinal regeneration. $A$, Expression of components of the $W n t / \beta$-catenin signaling pathway in the adult retina. RT-PCR analysis revealed that the adult rat retina expresses Wnt receptors: frizzled-1, frizzled-4, and frizzled- 9 and $L R P-5$ and $L R P-6$. The adult rat retina expresses Dishevelled, Axin-1, GSK-3 $\beta$, and $\beta$-catenin. Embryonic day 16.5 whole-brain cDNA was used as a positive control. $\boldsymbol{B}-\boldsymbol{D}$, The subcellular localization of $\beta$-catenin was examined by immunohistochemistry $(n=5)$. Arrowheads indicate nuclear accumulation of $\beta$-catenin. $\boldsymbol{B}$, In the non-injured retina, $\beta$-catenin is observed in the cytoplasm and at the plasma membrane. $\boldsymbol{C}$, In the damaged retina, a small number of cells show accumulation of $\beta$-catenin in the nucleus. $\boldsymbol{D}$, Wnt3a treatment promotes nuclear translocation of $\beta$-catenin. $\boldsymbol{E}$, Real-time PCR analysis of cyclin D1 expression. After injury, the level of cyclin D1 is upregulated between days 0 and 4 . Wnt3a treatment increases cyclin $D$ expression in the damaged retina. ${ }^{* *} p<0.01$ compared with injury alone (day 4). $(n=5) . \boldsymbol{F}-\boldsymbol{H}$, Involvement of Wnt/ $\beta$-catenin signaling in retinal regeneration in vivo. $(n=8) . \boldsymbol{F}$, In the intact retina of Wnt reporter TOPGAL mice, no cells express $\beta$-gal. G, $\beta$-Gal ${ }^{+}$cells are observed after NMDA-induced retinal injury. $\boldsymbol{H}$, Wnt3a increases the number of $\beta$-gal ${ }^{+}$cells in the NMDA-treated damaged retina. Note that $\beta$-gal ${ }^{+}$ cells possess Müller glia-like processes. IPL, Inner plexiform layer. Scale bars, $50 \mu \mathrm{m}$.
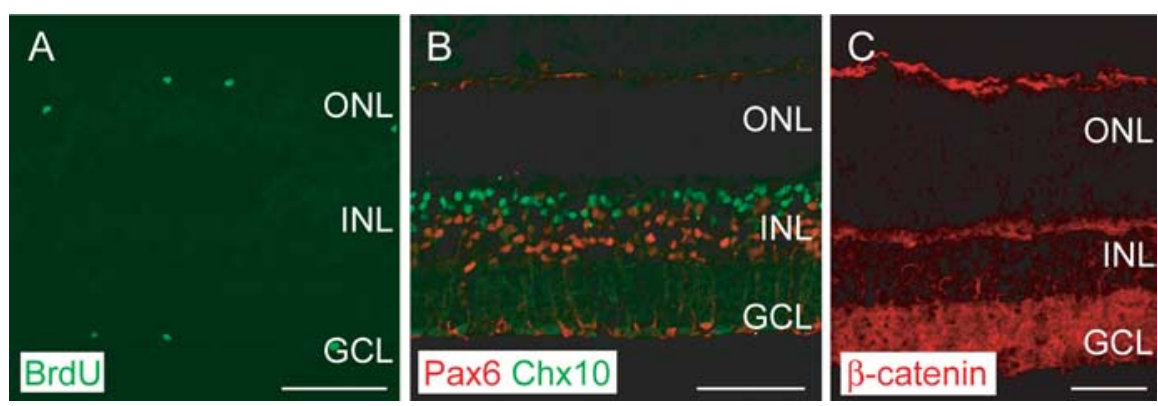

Figure 5. Blockade of Wnt signaling by Dkk-1 inhibits the retinal regeneration. $\boldsymbol{A}$, Treatment with Dkk-1 for $4 \mathrm{~d}$ significantly decreases the number of $\mathrm{BrdU}^{+}$cells in the INL of the damaged retina. Retinal explants from adult rats were treated with Dkk-1 $(100 \mathrm{ng} / \mathrm{ml})$ for $4 \mathrm{~d}(n=5)$. $\boldsymbol{B}$, Dkk-1 suppresses the generation of Pax $6^{+}$(red)/Chx10 ${ }^{+}$(green) retinal progenitors. C, Nuclear accumulation of $\beta$-catenin is blocked by Dkk-1. Scale bar, $100 \mu \mathrm{m}$. to day 0 (Fig. $4 E$ ). This result is consistent with the previous report that cyclin D1 expression was induced in Müller glia in the INL after retinal injury (Kohno et al., 2006). Wnt3a treatment caused a marked increase in cyclin D1 levels relative to the untreated damaged retina (Fig. $4 E$ ).

Next, we determined the involvement of $\mathrm{Wnt} / \beta$-catenin signaling in retinal regeneration process in vivo. We used Wnt/ $\beta$-catenin reporter mice (TOPGAL mice) in which a transgenic lac $Z$ reporter gene is specifically activated in response to $\mathrm{Tcf} /$ Lef (lethal factor)-mediated transcriptional activation by nuclear $\beta$-catenin. To induce neurotoxic injury in the adult retina, we injected $40 \mathrm{nmol}$ of NMDA, an agonist of glutamate receptors, into the vitreous chamber of adult TOPGAL mice eyes. After intravitreal injection of NMDA, TUNEL ${ }^{+}$cells were distributed in the INL and GCL (data not shown). In the NMDA-treated damaged retina, some cells were positive for $\beta$-gal (Fig. $4 G$ ), whereas no $\beta$-gal ${ }^{+}$cells were observed in the nontreated intact retina of TOPGAL mice (Fig. $4 F$ ). Wnt3a treatment markedly increased the number of $\beta$-gal ${ }^{+}$cells (Fig. $4 H$ ) in the NMDA-treated damaged retina. These $\beta$-gal ${ }^{+}$cells possessed Müller glia-like processes (Fig. 4G,H). These in vivo results were consistent with the results of retinal explants. These results indicate that $\mathrm{Wnt} / \beta$-catenin signaling plays a crucial role in intrinsic regeneration in the adult retina, and activation of the signaling promotes retinal regeneration.

Because injury induced nuclear accumulation of $\beta$-catenin, upregulation of $c y$ clin D1, and expression of $\beta$-gal in TOPGAL mice, we hypothesized that some spontaneous neural regeneration occurs after injury via the activation of $\mathrm{Wnt} / \beta$ catenin signaling. To investigate this possibility, we examined whether inhibiting Wnt signaling prevents neural regeneration after injury. Treating the damaged retina with Dkk-1 (100 ng/ml), a soluble negative modulator of Wnt signaling, significantly decreased the number of BrdUpositive cells in the INL $(3.8 \pm 0.6$ cells per field) (Fig. $5 A$ compared with Fig. 1C) compared with the untreated damaged retina $(1.7 \pm 0.2$ cells per field; $p<0.001$, an unpaired $t$ test). Dkk-1 also decreased the number of $\mathrm{Pax}^{+} / \mathrm{Chx} 10^{+}$retinal progenitors (Fig. 5B). Moreover, injuryinduced nuclear translocation of $\beta$-catenin was blocked by Dkk-1 (Fig. $5 C$ ). From these findings, we conclude that Wnt/ $\beta$-catenin signaling contributes to the intrinsic capacity for regeneration of the damaged retina. 

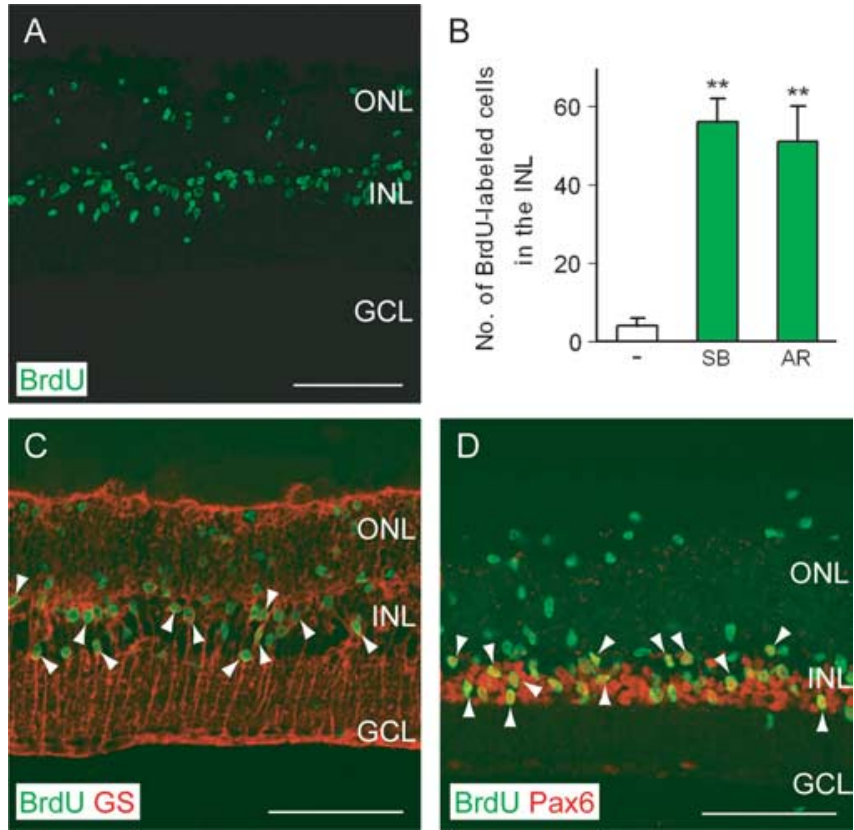

Figure 6. Inhibition of GSK-3 $\beta$ mimics the Wnt3a action. $\boldsymbol{A}$, Treatment with SB216763 increases the number of $\mathrm{BrdU}^{+}$cells in the INL. Retinal explants from adult rats were treated with SB216763 (5 $\mu \mathrm{M})$ for $4 \mathrm{~d}$ and processed for immunohistochemical analysis. $\boldsymbol{B}, \mathrm{GSK}-3 \beta$ inhibitors promote mitogenic activity. SB216763 (SB) or AR-A014418 (AR) was applied at $5 \mu \mathrm{M}$ for $4 d$. $^{* *} p<0.01$ compared with no treatment. $C$, Increase in the number of BrdU-labeled cells (green) positive for GS (red) in retinal explants treated with SB216763. D, SB216763 increases the number of BrdU ${ }^{+}$(green)/Pax6 ${ }^{+}($red) retinal progenitor cells $(\boldsymbol{A}-\boldsymbol{D} ; n=5)$ Arrowheads, Double-stained cells. Scale bars, $100 \mu \mathrm{m}$.

Because Wnt signaling leads to inhibition of GSK-3 $\beta$ and nuclear accumulation of $\beta$-catenin, we postulated that GSK- $3 \beta$ inhibitors may mimic the mitogenic action of Wnt3a on Müller glia. SB216763 and AR-A014418 are potent and specific inhibitors of GSK-3 $\beta$ (Coghlan et al., 2000; Bhat et al., 2003). Administration of SB216763 (5 $\mu \mathrm{M})$ for $4 \mathrm{~d}$ markedly and significantly increased the number of BrdU-labeled cells in the INL (Fig. 6A): $3.6 \pm 1.5$ cells per field were BrdU positive in the nontreated retina and $56.4 \pm 5.7$ cells per field in the SB216763-treated retina. Similar results were obtained when AR-A014418, an inhibitor that is structurally distinct from SB216763, was applied at 5 $\mu \mathrm{M}$ for $4 \mathrm{~d}$ (Fig. $6 \mathrm{~B}$ ). In retinas treated with SB216763, BrdUlabeled cells expressed both GS and Pax6 (Fig. 6C,D, arrowheads). These results indicate that GSK- $3 \beta$ inhibitors mimic the signaling by Wnt3a.

\section{Müller glia-derived progenitors differentiate into photoreceptors}

We examined whether the withdrawing Wnt3a treatment can lead to the differentiation of the retinal progenitor-like cells into retinal neurons. Retinal explants received Wnt3a treatment for $4 \mathrm{~d}$, followed by incubation in regular medium without Wnt3a for 7 more days. On day 11, the number of BrdU-labeled cells in the INL decreased, whereas the number in the ONL increased relative to the number of positive cells observed on day 4 in each layer (Fig. 7A-C). We evaluated the number of BrdU-labeled cells positive for GS. On day 4, $65.4 \pm 5.8 \%$ of the BrdU-labeled cells expressed GS, whereas the percentage of GS/BrdU double-positive cells was markedly decreased by day 11 ( $5.0 \pm 2.1 \%$ of BrdU-labeled cells; $p<0.01$ compared with on day 4 , unpaired $t$ test). We hypothesized that Müller glial cells in the INL proliferate, dedifferentiate into retinal progenitors, and then migrate into the ONL, in which they may differentiate into other types of retinal cells.

To determine whether proliferating cells acquire a new cell fate, we immunostained these cells with various retinal cellspecific markers. By day 11, BrdU-labeled cells in the ONL rarely expressed rhodopsin, a marker for rod photoreceptors (15.5 \pm $3.8 \%$ of BrdU-labeled cells). To promote differentiation of progenitor-like cells into photoreceptor cells, we tested the effects of RA on these cells, because RA is crucial for photoreceptor genesis (Hyatt and Dowling, 1997; Levine et al., 2000). Application of RA $(0.3 \mu \mathrm{M})$ for $7 \mathrm{~d}$ after Wnt3a treatment increased the number of BrdU-labeled cells positive for the early photoreceptor precursor marker Crx (Chen et al., 1997; Furukawa et al., 1997) (Fig. 7D, arrowheads). In addition, BrdU-labeled cells expressed the rod photoreceptor marker rhodopsin in the ONL (Fig. $7 E$, arrowheads). The number of rhodopsin ${ }^{+} / \mathrm{BrdU}^{+}$cells was significantly increased with RA treatment $(44.1 \pm 5.5 \%$ of BrdUlabeled cells; $p<0.01$ compared with the nontreated retina, unpaired $t$ test). Interestingly, a small number of Crx-positive cells were present in the INL, and the BrdU-labeled cells in the INL expressed Crx (Fig. 7D, arrow). These observations suggest that immature photoreceptor precursors migrate from the INL to the ONL. To obtain more evidence for the generation of retinal cells from BrdU-labeled cells, we examined the expression of retinal cell-specific markers in dissociated cells. Some BrdU-labeled cells expressed rhodopsin (Fig. 7F, arrowheads) or GS (Fig. 7G, arrowheads) after dissociation. We searched for other cell types with antibodies specific for particular neuronal subtypes, including Thy1.2 (a marker for ganglion cells), calbindin (a marker for horizontal cells), HPC-1 (a marker for amacrine cells), and PKC (a marker for bipolar cells). BrdU-labeled cells expressed none of these markers. We conclude that the Müller glia-derived retinal progenitors migrate into the ONL, and these cells differentiate into rod photoreceptor cells.

\section{Regeneration by Wnt signaling in the degenerating retina}

Finally, we examined whether Wnt3a also promotes the proliferation of progenitor-like cells in a genetic model of retinal degeneration. Retinitis pigmentosa comprises a group of inherited diseases in which photoreceptor degeneration leads to a loss of vision that may eventually culminate in blindness. The $r d$ mouse provides an adequate genetic model of this disease because the pattern of photoreceptor loss is similar to that in affected humans. Specifically, rod cell death is followed by cone cell degeneration (Bowes et al., 1990; McLaughlin et al., 1993). Mutant $r d$ mice exhibit a marked decrease in the number of photoreceptors by 1 postnatal month. We prepared the retinal explants from $r d$ mice on postnatal day 12 and cultured these explants in the presence or absence of Wnt3a $(100 \mathrm{ng} / \mathrm{ml})$ for $4 \mathrm{~d}$. Wnt3a $(100 \mathrm{ng} / \mathrm{ml})$ significantly increased the number of BrdU-labeled cells. Similar to our results using DA rat retinas, BrdU-labeled cells in the INL expressed GS (data not shown). However, distinct from DA rat retinas, BrdU was not incorporated into the retina of postnatal day $21 \mathrm{rd}$ mice or older even with Wnt3a treatment.

Next, we asked whether Müller glia-derived cells differentiate into retinal neurons in the degenerating retina. The retinal explants from $r d$ mice were treated with Wnt3a $(100 \mathrm{ng} / \mathrm{ml})$ for $4 \mathrm{~d}$ and subsequently cultured in regular medium without Wnt3a for $7 \mathrm{~d}$. Application of Wnt3a for $4 \mathrm{~d}$ significantly increased the number of BrdU-labeled cells in the ONL (Fig. 8A,B). Furthermore, we tested whether exogenous growth factors enhance the neurogenesis of photoreceptors. In addition to RA, NeuroD, a basic helix-loop-he- 

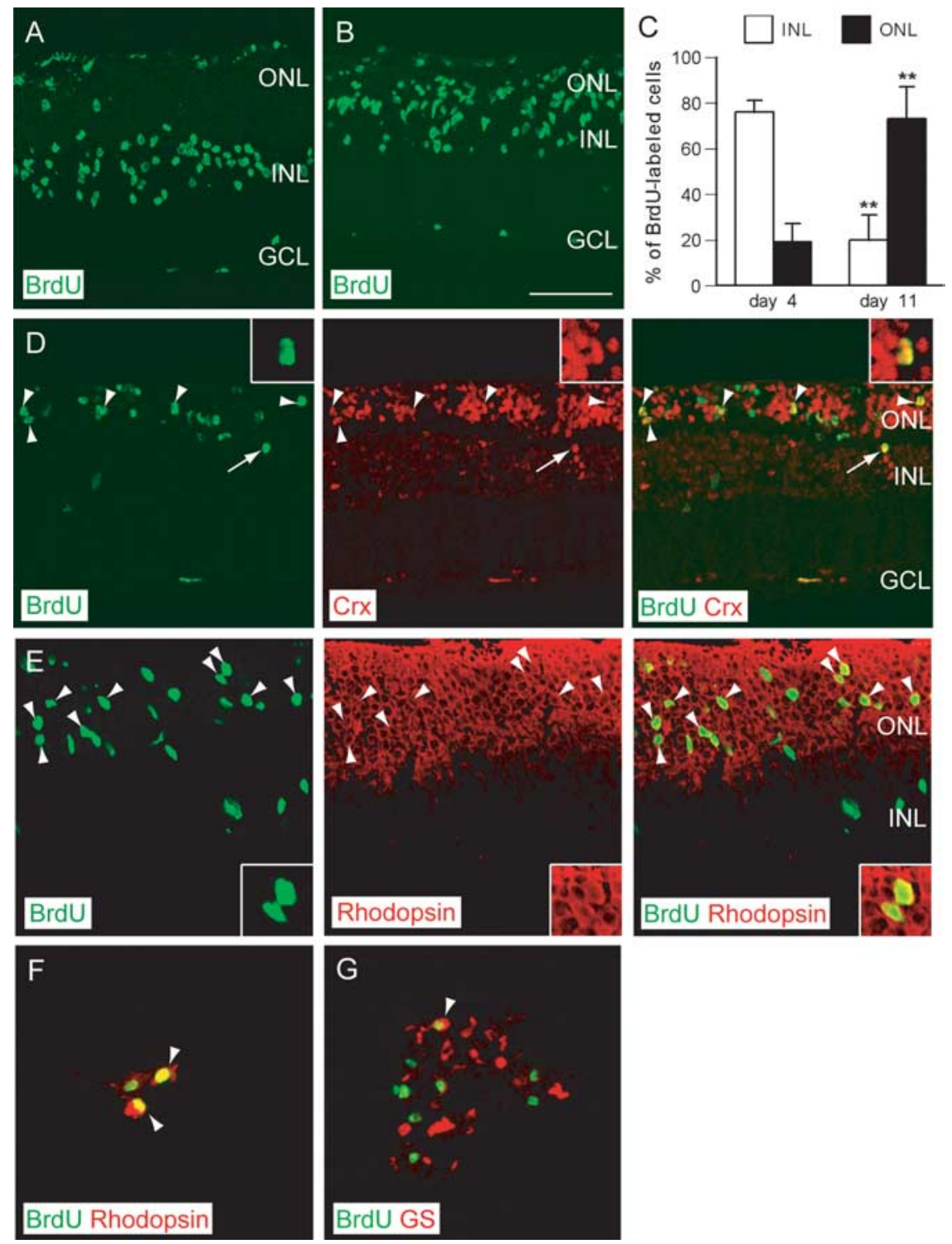

Figure 7. Newly generated cells migrate to the $0 \mathrm{NL}$ and differentiate into photoreceptors. $A$, Most BrdU-labeled cells (green) are in the INL of the Wnt3a-treated retina on day 4. B, On day 11, most BrdU-labeled cells (green) are in the ONL. C, Changes in the percentage of BrdU-labeled cells in the INL and ONL on days 4 and $11 .{ }^{* *} p<0.01$ compared with the corresponding layer on day 4. D, BrdU-labeled cells (green) express the photoreceptor precursor marker $\mathrm{Crx}(\mathrm{red})$. The arrow indicates that precursor cells migrate from the INL to the ONL.E, BrdU-labeled cells (green) express the photoreceptor marker rhodopsin (red) in the ONL on day 11. Insets, Magnified view of double-labeled cells. Retinal explants from adult rats were treated with Wnt3a (100 $\mathrm{ng} / \mathrm{ml})$ for $4 \mathrm{~d}$ and subsequently with RA $(0.3 \mu \mathrm{m})$ for an additional $7 \mathrm{~d}(\boldsymbol{A}-\boldsymbol{E} ; n=10) . \boldsymbol{F}$, Coimmunolocalization of BrdU (green) and rhodopsin (red) after dissociation. $\mathbf{G}$, Cells expressing BrdU (green) and GS (red) after dissociation $(\boldsymbol{F}, \mathbf{G} ; n=3)$. Arrowheads, Double-stained cells. Scale bar, $100 \mu \mathrm{m}$.

lix transcription factor, also participates in photoreceptor development (Hatakeyama and Kageyama, 2004; Yan et al., 2005). NeuroD expression was regulated by histone deacetylases (Lunyak et al., 2002), and the histone deacetylase inhibitor VPA induced NeuroD expression in neural stem cells (Hsieh et al., 2004). We applied RA $(0.3 \mu \mathrm{M})$ or VPA $(1 \mathrm{mM})$ for $7 \mathrm{~d}$ after $4 \mathrm{~d}$ treatment with Wnt3a (100 $\mathrm{ng} / \mathrm{ml})$. Neither treatment increased the number of, or changed the distribution of, BrdU-labeled cells in either the central or peripheral region of the retina (data not shown). The number of rhodopsin/ BrdU double-positive cells in the ONL of the central retina was markedly increased by RA or VPA (Fig. $8 C-E$ ), whereas the overall number of BrdU-labeled cells remained constant. Although BrdUlabeled cells were rarely positive for rhodopsin in nontreated retina $(3.1 \pm 1.0 \%)$ (Fig. $8 C$ ), $13.9 \pm 2.4 \%$ of the BrdU-labeled cells ex- pressed rhodopsin in the RA-treated retinas (Fig. 8D, arrowheads) and $18.2 \pm 3.8 \%$ in the VPA-treated retinas (Fig. $8 E$, arrowheads), respectively. BrdU-labeled cells were not immunopositive for any other retinal neuronal markers. We also confirmed that BrdU-labeled cells in the ONL were TUNEL negative in the RA- or VPA-treated retina (data not shown). Thus, in the degenerating retina, Wnt3a increased cell proliferation, and treatment with RA or VPA promoted the differentiation of these cells into rhodopsin-positive photoreceptor cells.

\section{Discussion}

In the present study, activation of $\mathrm{Wnt} / \beta$ catenin signaling by Wnt3a or inhibitors of GSK-3 $\beta$ promoted proliferation of Müller glia-derived retinal progenitors and neural regeneration in the retina. Conversely, inhibiting Wnt signaling with Dkk-1 attenuated retinal regeneration. We conclude from these findings that a repair process mediated by $\mathrm{Wnt} / \beta$ catenin signaling exists in vivo, and we can promote regeneration of retinal neurons by applying Wnt or GSK-3 $\beta$ inhibitors to the retina. Although Lie et al. (2005) have shown that Wnt signaling is required for adult hippocampal neurogenesis under physiological conditions, this study provides the first evidence that $\mathrm{Wnt} / \beta$ catenin signaling contributes to CNS regeneration after damage in the presence of pathological conditions.

Insulin and fibroblast growth factor-2 promote the regeneration of Müller glia in the postnatal chick retina (Fischer and Reh, 2001; Fischer et al., 2002). However, these factors have no effect in the adult mammalian retina (Ooto et al., 2004). Accumulating evidence indicates that several factors promote proliferation of neural progenitor cells in vitro and in vivo (Ming and Song, 2005). For example, continuous intraventricular infusion of epidermal growth factors or FGF promotes neuronal regeneration (Kuhn et al., 1997; Nakatomi et al., 2002). The effects of these growth factors are not, however, restricted to progenitor cells. They also act on vascular cells and fibroblasts. The proliferation of these cells can cause irreversible damage to the eye when injected into the vitreous cavity, such as retinal neovascularization or proliferative vitreoreinopathy. Compared with these factors, the activators of $\mathrm{Wnt} / \beta$-catenin pathway seem to be more selective in their effects. Although several reports support the involvement of Wnt signaling in cancer formation, an aberrant Wnt pathway is usually activated in these situations because of mutations of the pathway components such as adenomatous polyposis coli and $\beta$-catenin (Polakis, 2000; Reya and Clevers, 2005). Intrinsic Wnt signaling has not been reported to form tumors, because endogenous Wnt levels are quite limited. Indeed, we did not observe 
any tumor formation or any clusters of proliferating cells in the retina.

We cannot entirely exclude the possibility that the newly generated neurons we observed were produced by sparsely distributed populations of quiescent neural stem cells. However, the existence of quiescent neural stem cells in the neural retina of adult mammals has not been reported. Although retinal progenitor cells are present in the ciliary marginal zone of adult mammals (Tropepe et al., 2000), Müller glia appear to contribute more to regeneration in the central retina in our explant culture system, which is depleted of most of the peripheral part of the retina. Wnt receptors in the INL in the adult retina may contribute to the regenerative process in the damaged retina.

Interestingly, most newly generated cells migrated toward the outer layers of the retina in the present study. In contrast, we observed previously that newly generated cells moved toward both the outer and inner layers in which NMDA had induced the death of retinal ganglion cells and amacrine cells (Ooto et al., 2004). The degenerating cells in these retinal explants were predominantly in the ONL. This feature might promote the migration of proliferating cells toward the outer part of the retina. Although several lines of evidence suggest that chemokines and matrix metalloproteases are involved in the migration of neural progenitors toward injured brain sites (Imitola et al., 2004; Belmadani et al., 2006; Lee et al., 2006), it is not clear what kinds of factors determine the fate of regenerating cells in the retina.

It should be noted that the degenerating retina retains some capacity for neural cell regeneration. Additionally, we observed the regenerative potential in the primate retina (supplemental Fig. 1, available at www.jneurosci.org as supplemental material). Together with our previous study demonstrating the generation of new retinal neurons in vivo (Ooto et al., 2004), these findings may offer hope for patients with retinal degenerative diseases such as retinitis pigmentosa. Considering the risks associated with invasive surgery and rejection of grafted cells, therapies that promote the activation of endogenous retinal progenitors would have significant advantages over cell transplantation. To use endogenous regenerative processes effectively, some manipulation is required to enhance the proliferation of progenitor cells and differentiate these cells appropriately. Particularly, eyes are one of the tissues in which drugs can be locally administered. Therefore, we propose that modulating the $\mathrm{Wnt} / \beta$ catenin pathway is one possible therapeutic strategy to enhance replacement of lost neurons by generating cells derived from endogenous neuronal progenitors. Although the number of photoreceptor cells that was generated by proliferating cells in our study is encouraging, additional study is required to confirm that the regenerated photoreceptor cells are integrated into functional neural circuit within the retina. It is also important to note that the progression of the disease may restrict the potential degree of recovery, because the regenerative capacity of the retina seems to be lost as the retina degenerates.
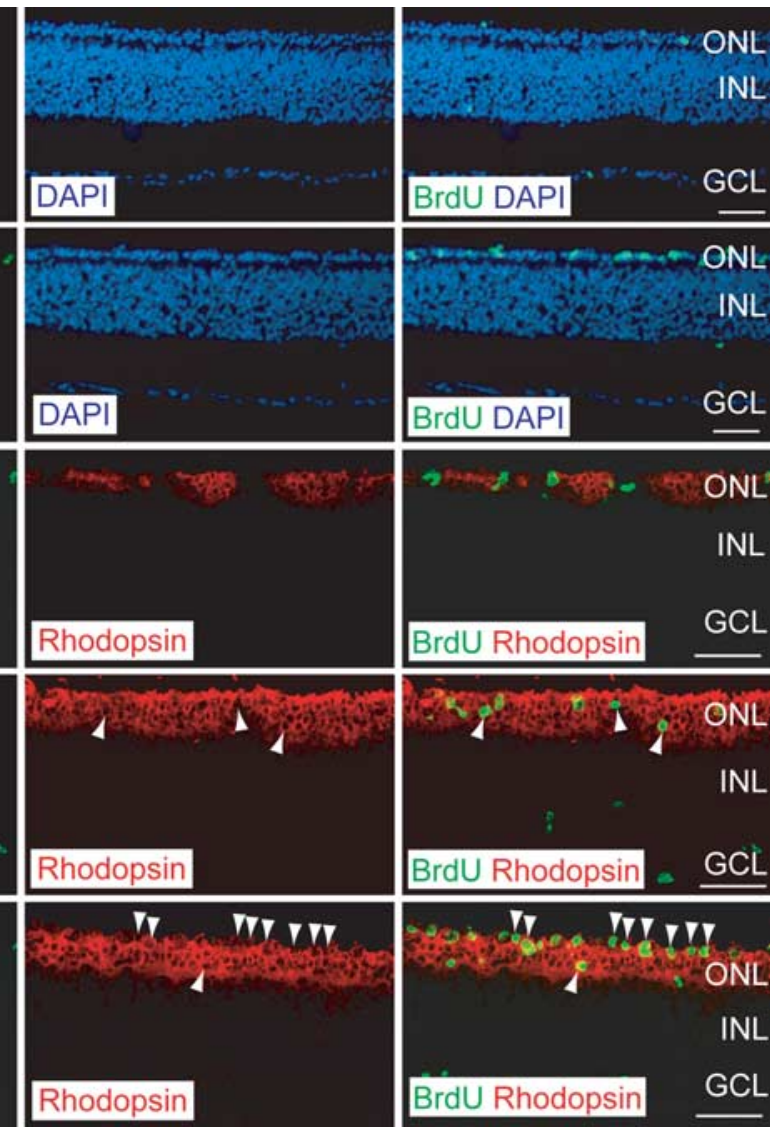

\section{.}

.

Figure 8. Retinal regeneration by Wnt3a in the retinal degeneration model. $\boldsymbol{A}$, BrdU-labeled cells (green) in the retinal explants 列 mice were treated with Wnt3a $(100 \mathrm{ng} / \mathrm{ml})$ for $4 \mathrm{~d}$ and subsequently with RA $(0.3 \mu \mathrm{M})$ orVPA $(1 \mathrm{~mm})$ for $7 \mathrm{~d}(\boldsymbol{A}-\boldsymbol{E} ; n=8)$ le bar, $50 \mu \mathrm{m}$

In summary, the present study provides the first evidence that Wnt/ $\beta$-catenin signaling pathway regulates the regeneration of neurons after injury in the adult mammalian CNS. This pathway contributes to the intrinsic mechanisms of regeneration after injury, and this innate activity can be further enhanced by the addition of exogenous activators of the $\mathrm{Wnt} / \beta$-catenin pathway. Thus, lowmolecular compounds that activate $\mathrm{Wnt} / \beta$-catenin signaling, such as Wnt receptor agonists (Liu et al., 2005) and GSK-3 $\beta$ inhibitors (Cohen and Goedert, 2004), may have therapeutic potential for promoting the regeneration of retinal neurons.

\section{References}

Ahmad I, Tang L, Pham H (2000) Identification of neural progenitors in the adult mammalian eye. Biochem Biophys Res Commun 270:517-521.

Alvarez-Buylla A, Garcia-Verdugo JM (2002) Neurogenesis in adult subventricular zone. J Neurosci 22:629-634.

Arvidsson A, Collin T, Kirik D, Kokaia Z, Lindvall O (2002) Neuronal replacement from endogenous precursors in the adult brain after stroke. Nat Med 8:963-970.

Belecky-Adams T, Tomarev S, Li HS, Ploder L, McInnes RR, Sundin O, Adler R (1997) Pax-6, Prox 1, and Chx10 homeobox gene expression correlates with phenotypic fate of retinal precursor cells. Invest Ophthalmol Vis Sci 38:1293-1303.

Belmadani A, Tran PB, Ren D, Miller RJ (2006) Chemokines regulate the migration of neural progenitors to sites of neuroinflammation. J Neurosci 26:3182-3191.

Bhat R, Xue Y, Berg S, Hellberg S, Ormo M, Nilsson Y, Radesater AC, Jerning 
E, Markgren PO, Borgegard T, Nylof M, Gimenez-Cassina A, Hernandez F, Lucas JJ, Diaz-Nido J, Avila J (2003) Structural insights and biological effects of glycogen synthase kinase 3-specific inhibitor AR-A014418. J Biol Chem 278:45937-45945.

Blackshaw S, Harpavat S, Trimarchi J, Cai L, Huang H, Kuo WP, Weber G, Lee K, Fraioli RE, Cho SH, Yung R, Asch E, Ohno-Machado L, Wong WH, Cepko CL (2004) Genomic analysis of mouse retinal development. PLoS Biol 2:E247.

Bowes C, Li T, Danciger M, Baxter LC, Applebury ML, Farber DB (1990) Retinal degeneration in the rd mouse is caused by a defect in the beta subunit of rod cGMP-phosphodiesterase. Nature 347:677-680.

Chen S, Wang QL, Nie Z, Sun H, Lennon G, Copeland NG, Gilbert DJ, Jenkins NA, Zack DJ (1997) Crx, a novel Otx-like paired-homeodomain protein, binds to and transactivates photoreceptor cell-specific genes. Neuron 19:1017-1030.

Coghlan MP, Culbert AA, Cross DA, Corcoran SL, Yates JW, Pearce NJ, Smith DG, Murray KJ, Reith AD, Holder JC (2000) Selective small molecule inhibitors of glycogen synthase kinase- 3 modulate glycogen metabolism and gene transcription. Chem Biol 7:793-803.

Cohen P, Goedert M (2004) GSK3 inhibitors: development and therapeutic potential. Nat Rev Drug Discov 3:479-487.

DasGupta R, Fuchs E (1999) Multiple roles for activated LEF/TCF transcription complexes during hair follicle development and differentiation. Development 126:4557-4568.

Domingos PM, Itasaki N, Jones CM, Mercurio S, Sargent MG, Smith JC, Krumlauf R (2001) The Wnt/beta-catenin pathway posteriorizes neural tissue in Xenopus by an indirect mechanism requiring FGF signalling. Dev Biol 239:148-160.

Fischer AJ, Reh TA (2001) Müller glia are a potential source of neural regeneration in the postnatal chicken retina. Nat Neurosci 4:247-252.

Fischer AJ, Reh TA (2003) Growth factors induce neurogenesis in the ciliary body. Dev Biol 259:225-240.

Fischer AJ, McGuire CR, Dierks BD, Reh TA (2002) Insulin and fibroblast growth factor 2 activate a neurogenic program in Muller glia of the chicken retina. J Neurosci 22:9387-9398.

Furukawa T, Morrow EM, Cepko CL (1997) Crx, a novel otx-like homeobox gene, shows photoreceptor-specific expression and regulates photoreceptor differentiation. Cell 9:531-541.

Gage FH (2000) Mammalian neural stem cells. Science 287:1433-1438.

Hall AC, Lucas FR, Salinas PC (2000) Axonal remodeling and synaptic differentiation in the cerebellum is regulated by WNT-7a signaling. Cell 100:525-535.

Hatakeyama J, Kageyama R (2002) Retrovirus-mediated gene transfer to retinal explants. Methods 28:387-395.

Hatakeyama J, Kageyama R (2004) Retinal cell fate determination and bHLH factors. Semin Cell Dev Biol 15:83-89.

Hsieh J, Nakashima K, Kuwabara T, Mejia E, Gage FH (2004) Histone deacetylase inhibition-mediated neuronal differentiation of multipotent adult neural progenitor cells. Proc Natl Acad Sci USA 101:16659-16664.

Hyatt GA, Dowling JE (1997) Retinoic acid. A key molecule for eye and photoreceptor development. Invest Ophthalmol Vis Sci 38:1471-1475.

Ikeda H, Osakada F, Watanabe K, Mizuseki K, Haraguchi T, Miyoshi H, Kamiya D, Honda Y, Sasai N, Yoshimura N, Takahashi M, Sasai Y (2005) Generation of $\mathrm{Rx}+/ \mathrm{Pax} 6+$ neural retinal precursors from embryonic stem cells. Proc Natl Acad Sci USA 102:11331-11336.

Imitola J, Raddassi K, Park KI, Mueller FJ, Nieto M, Teng YD, Frenkel D, Li J, Sidman RL, Walsh CA, Snyder EY, Khoury SJ (2004) Directed migration of neural stem cells to sites of CNS injury by the stromal cell-derived factor 1alpha/CXC chemokine receptor 4 pathway. Proc Natl Acad Sci USA 101:18117-18122.

Inoue T, Kagawa T, Fukushima M, Shimizu T, Yoshinaga Y, Takada S, Tanihara H, Taga T (2006) Activation of canonical Wnt pathway promotes proliferation of retinal stem cells derived from adult mouse ciliary margin. Stem Cells 24:95-104.

Jessberger S, Kempermann G (2003) Adult-born hippocampal neurons mature into activity-dependent responsiveness. Eur J Neurosci 18:2707-2712.

Kiecker C, Niehrs C (2001) A morphogen gradient of Wnt/beta-catenin signalling regulates anteroposterior neural patterning in Xenopus. Development 128:4189-4201.

Kohno H, Sakai T, Kitahara K (2006) Induction of nestin, Ki-67, and cyclin D1 expression in Muller cells after laser injury in adult rat retina. Graefes Arch Clin Exp Ophthalmol 244:90-95.
Kubo F, Takeichi M, Nakagawa S (2003) Wnt2b controls retinal cell differentiation at the ciliary marginal zone. Development 130:587-598.

Kuhn HG, Winkler J, Kempermann G, Thal LJ, Gage FH (1997) Epidermal growth factor and fibroblast growth factor-2 have different effects on neural progenitors in the adult rat brain. J Neurosci 17:5820-5829.

Lee SR, Kim HY, Rogowska J, Zhao BQ, Bhide P, Parent JM, Lo EH (2006) Involvement of matrix metalloproteinase in neuroblast cell migration from the subventricular zone after stroke. J Neurosci 26:3491-3495.

Levine EM, Fuhrmann S, Reh TA (2000) Soluble factors and the development of rod photoreceptors. Cell Mol Life Sci 57:224-234.

Li Y, Schlamp CL, Poulsen GL, Jackson MW, Griep AE, Nickells RW (2002) p53 regulates apoptotic retinal ganglion cell death induced by $N$-methylD-aspartate. Mol Vis 8:341-350.

Lie DC, Colamarino SA, Song HJ, Desire L, Mira H, Consiglio A, Lein ES, Jessberger S, Lansford H, Dearie AR, Gage FH (2005) Wnt signalling regulates adult hippocampal neurogenesis. Nature 437:1370-1375.

Liu H, Mohamed O, Dufort D, Wallace VA (2003) Characterization of Wnt signaling components and activation of the Wnt canonical pathway in the murine retina. Dev Dyn 227:323-334.

Liu J, Wu X, Mitchell B, Kintner C, Ding S, Schultz PG (2005) A smallmolecule agonist of the Wnt signaling pathway. Angew Chem Int Ed Engl 44:1987-1990.

Lunyak VV, Burgess R, Prefontaine GG, Nelson C, Sze SH, Chenoweth J, Schwartz P, Pevzner PA, Glass C, Mandel G, Rosenfeld MG (2002) Corepressor-dependent silencing of chromosomal regions encoding neuronal genes. Science 298:1747-1752.

Lyuksyutova AI, Lu CC, Milanesio N, King LA, Guo N, Wang Y, Nathans J, Tessier-Lavigne M, Zou Y (2003) Anterior-posterior guidance of commissural axons by Wnt-frizzled signaling. Science 302:1984-1988.

Magavi SS, Leavitt BR, Macklis JD (2000) Induction of neurogenesis in the neocortex of adult mice. Nature 405:951-955.

Marquardt T, Gruss P (2002) Generating neuronal diversity in the retina: one for nearly all. Trends Neurosci 25:32-38.

McLaughlin ME, Sandberg MA, Berson EL, Dryja TP (1993) Recessive mutations in the gene encoding the beta-subunit of rod phosphodiesterase in patients with retinitis pigmentosa. Nat Genet 4:130-134.

Ming GL, Song H (2005) Adult neurogenesis in the mammalian central nervous system. Annu Rev Neurosci 28:223-250.

Nakatomi H, Kuriu T, Okabe S, Yamamoto S, Hatano O, Kawahara N, Tamura A, Kirino T, Nakafuku M (2002) Regeneration of hippocampal pyramidal neurons after ischemic brain injury by recruitment of endogenous neural progenitors. Cell 110:429-441.

Ooto S, Akagi T, Kageyama R, Akita J, Mandai M, Honda Y, Takahashi M (2004) Potential for neural regeneration after neurotoxic injury in the adult mammalian retina. Proc Natl Acad Sci USA 101:13654-13659.

Polakis P (2000) Wnt signaling and cancer. Genes Dev 14:1837-1851.

Raymond PA, Hitchcock PF (2000) How the neural retina regenerates. Results Probl Cell Differ 31:197-218.

Reya T, Clevers H (2005) Wnt signalling in stem cells and cancer. Nature 434:843-850.

Reya T, Duncan AW, Ailles L, Domen J, Scherer DC, Willert K, Hintz L, Nusse R, Weissman IL (2003) A role for Wnt signalling in self-renewal of haematopoietic stem cells. Nature 423:409-414.

Schmidt-Hieber C, Jonas P, Bischofberger J (2004) Enhanced synaptic plasticity in newly generated granule cells of the adult hippocampus. Nature 429:184-187.

Shtutman M, Zhurinsky J, Simcha I, Albanese C, D’Amico M, Pestell R, and Ben-Ze'ev A (1999) The cyclin D1 gene is a target of the beta-catenin/ LEF-1 pathway. Proc Natl Acad Sci USA 96:5522-5527.

Tetsu O, McCormick F (1999) Beta-catenin regulates expression of cyclin D1 in colon carcinoma cells. Nature 398:422-426.

Tropepe V, Coles BL, Chiasson BJ, Horsford DJ, Elia AJ, McInnes RR, van der Kooy D (2000) Retinal stem cells in the adult mammalian eye. Science 287:2032-2036.

van Praag H, Schinder AF, Christie BR, Toni N, Palmer TD, Gage FH (2002) Functional neurogenesis in the adult hippocampus. Nature 415:1030-1034.

Van Raay TJ, Vetter ML (2004) Wnt/frizzled signaling during vertebrate retinal development. Dev Neurosci 26:352-358.

Wodarz A, Nusse R (1998) Mechanisms of Wnt signaling in development. Annu Rev Cell Dev Biol 14:59-88.

Yan RT, Ma W, Liang L, Wang SZ (2005) bHLH genes and retinal cell fate specification. Mol Neurobiol 32:157-171. 